Journal of Mathematics and Statistics 6 (2): 168-173, 2010

ISSN 1549-3644

(C) 2010 Science Publications

\title{
Capital Structure and Corporate Performance in Nigeria Petroleum Industry: Panel Data Analysis
}

\author{
${ }^{1}$ Dare Funso David and ${ }^{2}$ Sola Olorunfemi \\ ${ }^{1}$ Department of Banking and Finance, Adekunle Ajasin University, \\ P.M.B. 001, Akungba Akoko, Ondo State, Nigeria \\ ${ }^{2}$ Department of Economics, Adekunle Ajasin University, P.M.B. 001, \\ Akungba Akoko, Ondo State, Nigeria
}

\begin{abstract}
Problem statement: The actual impact of capital structure on corporate performance in Nigeria has been a major problem among researchers that has not been resolved. Approach: The study looks at the impact of capital structure on corporate performance in the Nigerian Petroleum Industry. Results: The study employed panel data analysis by using Fixed-effect estimation, Random-effect estimation and Maximum likelihood estimation. It was found out that there was positive relationship between earnings per share and leverage ratio on one hand and positive relationship between dividend per share and leverage ratio on the other hand. Conclusion/Recommendations: It is therefore recommended that the management of the industry should do more to improve on its leverage ratio.
\end{abstract}

Key words: Leverage ratio, dividend, earnings per share, fixed effect and random effect

\section{INTRODUCTION}

An appropriate capital structure is a critical decision for any business organization. The decision is important not only because of the need to maximize returns to various organizational constituencies, but also because of the impact such a decision has on an organization's ability to deal with its competitive environment.

A company can finance investment decision by debt and/or equity. This is known as financing decision which could affect the debt- equity mix of firms. The debt-equity mix has an overall implication for the shareholders earnings and risk which will in turn affect the cost of capital and market value of the company.

It is therefore imperative for financial managers of firms to determine the proportion of equity capital and debt capital (capital structure) to obtain the debt financing mix, that is, an optimal capital structure.

Capital structure is used to represent the proportionate relationship between debt and equity. Equity includes paid-up share capital, share premium, reserves and retained earnings.

The debt-equity mix can take any of the following forms: $100 \%$ equity: $0 \%$ debt, $0 \%$ equity: $100 \%$ debt and $\mathrm{X} \%$ equity: $\mathrm{Y} \%$ debt. From these three alternatives, option one is that of the Unlevered firm, that is, the firm shuns the advantage of leverage (if any). Option two may not actually be realistic or possible in real life economic situation because no provider of funds will invest his money in a firm without equity capital. This partially explains the term "trading on equity", that is, it is the equity element that is present in the firm's capital structure that encourages the debt providers to give their scarce resources to the business, option three is the most realistic one in that it combined both a certain percentage of debt and equity in the capital structure and thus, the advantages of leverage (if any) is exploited.

This study is aimed at testing the impact of capital structure on corporate performance of Nigerian firms. The study is however focused on the Nigerian Petroleum Industry.

Capital structure theories have attracted a great attention in the field of financial management and also has its attendant controversies. A firm's capital structure decision can not be brush aside because of its ultimate effect on the value of the firm, Weighted Average Cost of Capital (WACC) and other salient variables.

A financial expert (Pandey, 1999) differentiated between capital structure and financial structure. $\mathrm{He}$ affirms that the various means used to raise funds represented the financial structure of the enterprise. He defined capital structure as the proportionate relationship between long-term debt and equity. Equity

Corresponding Author: Dare Funso David, Department of Banking and Finance, Adekunle Ajasin University, P.M.B. 001, Akungba Akoko, Ondo State, Nigeria 
is also defined to include share-capital, share premium, Reserves and surplus (Retained earnings). Equity is a good source of capital to business, particularly, the fund from the stock market has been a source of capital for the corporate sector. Emmanuga (1998) in his study on private sector dependence on capital market funds in Nigeria (Edo, 1997), using autoregressive model and estimation techniques, found out that capital market funds made a positive but insignificant impact on private sector.

Capital structure is the proportions of debt instruments and preferred and common stock on a company's balance sheet (Van Horne, 2002). The firm's mix of different securities is known as its capital structure. The choice of capital structure is fundamentally a marketing problem. The firm can issue dozens of distinct securities in countless combinations, but it attempts to find the particular combination that maximizes it's overall market value (Brealey and Myers, 1996).

The effect of capital structure on the overall cost of capital in one hand and the value of the firm on the other hand has been a major source of controversy among finance scholars (Oloyede and Akinmulegun, 1999). This has also led to the controversy over the existence of optimum capital structure.

Different school of thoughts that we can group into four approaches have been identified (Olowe, 1998):

- Net income approach

- Net operating income approach

- Traditional approach

- Modigliani and miller theory

The net income approach takes the view that leverage or capital structure can affect the value of the firm or it's cost of capital. If a firm increase the debt in its capital structure, the value of the firm will increase while the overall cost of capital will be reduced. This approach assumes that the cost of debt is less than the cost of equity. The net income approach is illustrated graphically in Fig. 1.

As debt in the capital structure is increased, the weighted average cost of capital $\left(\mathrm{K}_{\mathrm{o}}\right)$ decreases and approaches the cost of debt since debt is a cheaper source of finance. An optimum capital structure will occur at the point where the value of the firm is maximum and the weighted average cost of capital is minimum.

From Fig. 1, an optimum capital structure will occur at the point when the firm is $100 \%$ debt financed. The Net Operating Income Approach on the other hand holds that financial leverage or capital

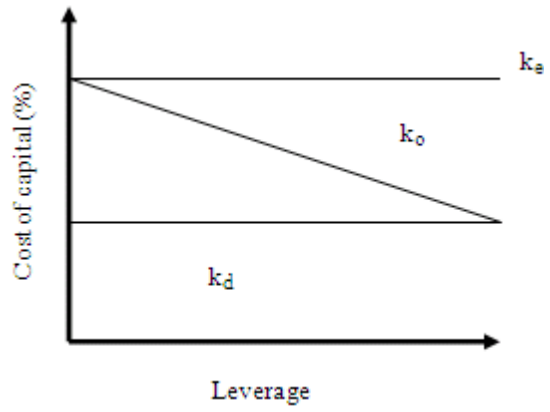

Fig. 1: Financial leverage and the cost of capital under the net income approach

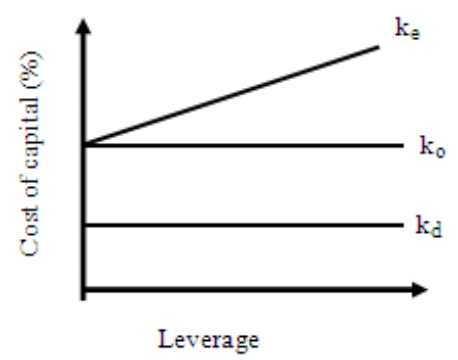

Fig. 2: Financial leverage and the cost of capital under the net operating income approach

structure changes do not affect the market value of the firm or the weighted average cost of capital. The net operating income is capitalized at the overall capitalization rate or weighted average cost of capital $\left(\mathrm{k}_{\mathrm{o}}\right)$ to obtain the total market value of the firm. This approach assumes that the weighted average cost of capital $\left(\mathrm{k}_{\mathrm{o}}\right)$ depends on the business risk. Since business risk is constant, this $\mathrm{K}_{\mathrm{o}}$ is constant regardless of the degree of leverage. It assumes further that the cost of debt $\left(\mathrm{k}_{\mathrm{d}}\right)$ is constant regardless of the degree of leverage and is cheaper than the cost of equity.

The net operating income approach can be shown graphically as in Fig. 2. It can be seen from the Fig. 2 that $\mathrm{k}_{\mathrm{o}}$ and $\mathrm{k}_{\mathrm{d}}$ are constant while $\mathrm{k}_{\mathrm{e}}$ increases linearly with leverage. As the cost of capital is constant at any level of leverage, there is no unique optimum capital structure in this approach.

The Traditional Approach is a modification to the net income approach. Olowe (1998) affirms that it is regarded as a middle of the road position between the net income approach and the net operating income approach. The traditional approach to leverage assumes that the value of the firm can be increased or the cost of capital reduced through judicious use of leverage.

The approach suggests that the value of the firm increase or the cost of capital decreases initially within a reasonable limit of debt after which further increase in leverage reduces the value of the firm or increases the 


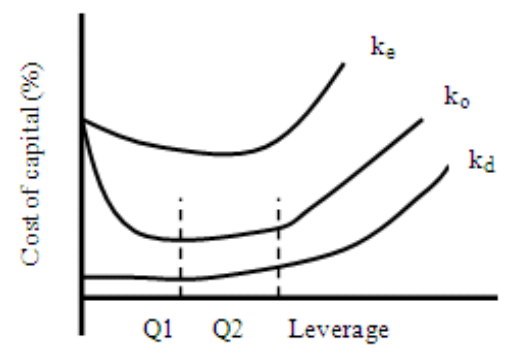

Fig. 3: Leverage and the cost of capital under the traditional approach

cost of capital. Thus, in the traditional approach, an optimum capital structure exists and it occurs when the market value of the firm is maximum and the cost of capital is minimum.

The traditional approach can be depicted graphically as in Fig. 3.

In Fig. 3, the cost of capital first decreases with leverage and later increases with leverage. The range Q1 and Q2 is the point of optimum capital structure (Modigliani and Miller, 1958). Challenged the traditional view as to the effect of leverage on the cost of capital. They developed a behavioral justification support for the net operating income approach. Without taxes, the cost of capital and market value of the firm remain constant throughout all degrees of leverage (Modigliani and Miller, 1958). Modified their theory to admit that tax relief on interest payment does lower the Weighted Average Cost of Capital (WACC) and came to a different conclusion that the WACC will always continue to fall, up to a leverage level of $100 \%$.

Following the Modigliani and Miller (1958) article, Vermale (1981) presented an empirical result which is inconsistent with the $\mathrm{M}$ and $\mathrm{M}$ theories but agrees with the traditional view. They concluded that the cost of capital is affected by debt, apart from it's tax advantage and that investors prefer corporate to personal leverage and therefore, the value of a firm rises up to a leverage range considered prudent. Other studies that arrived at similar conclusion includes (Rajan and Zingales, 1995; Wald, 1999; Champion, 1999)

Also, empirical studies by (Ross, 1977; Noe, 1988; Israel, 1992; Demirguc-Kunt and Maksimovic, 1999; Andy et al., 2002) confirmed that there is a positive correlation between leverage and the value of the firm.

In all, a critical examination of the results reveals that the empirical evidence on the subject is so inconclusive that it offers little in terms of either resolving conflicting theoretical propositions or aiding the decision makers. This is because, while some research findings led to the conclusion that leverage has positive impact on share price, some concluded that the relationship is negative. According to Andy et al. (2002) affirmed in their study that despite the extensive body of literature surrounding the question of an optimal capital structure and the numerous attempts to explain capital structure determinants, efforts have proved to be inconclusive.

\section{MATERIALS AND METHODS}

Theoretical framework: Theoretically, there is a positive relationship between the leverage ratio and dividend per share given a cross section time series data surveyed over a given time span of this study, the equation showing the relationship can be specified as a cross sectional regression at $\mathrm{t}=7$ as:

$\mathrm{Yi}_{7}=\alpha_{0}+\alpha_{1} \mathrm{Xi}_{7}+\mathrm{Ni}_{7}$

This Eq. 1 is biased because of endogeneity of $\mathrm{X}$ and $\mathrm{N}$. There is the need to identify the true causal effect. The data can be pool and thereafter estimate its OLS regression as:

Yit $=\alpha_{0}+\alpha_{1} \mathrm{Xit}+\mathrm{Nit}$

This Eq. 2 is still biased because of unobserved heterogeneity (Uit and Xit are correlated). This problem is said to be removed if the error term is decompose into two components so that:

$\mathrm{Uit}=\mathrm{Vi}+\mathrm{Yit}$

$\mathrm{Vi}$ is the person- specific error and Yit is the idiosyncratic error. Equation 2 become:

Yit $=\alpha 1 X i t+V i+Y i t$

Theoretically Vi does not change over time every person has a fixed value on this latent variable (fixed effect) and it represents person- specific time constant unobserved heterogeneity. It must be noted in this study V1 is the unobserved and it is constant over the six years.

However, Yit varies over firms and time and fulfill the classical assumption of OLS error terms. With panel data as it is used in this study we can easily difference out Vit as:

$$
\begin{aligned}
& \mathrm{Yi} 2=\alpha_{1} \mathrm{Xi2}+\mathrm{Vi}+\mathrm{Yi} 2 \\
& \mathrm{Yi1}=\alpha_{1} \mathrm{Xi1}+\mathrm{Vi}+\mathrm{Yi} 1
\end{aligned}
$$

Subtracting (6) from (5) we get: 


$$
\Delta \mathrm{yi}=\beta \mathrm{i} \Delta \mathrm{Xi}+\Delta \mathrm{Yi}
$$

Equation 7 is theoretically said not to be good as the estimator may not be efficient because the standard error will be biased. To remedy this, the Huber- while sandwich estimator is suggested. An alternative to Eq. 7 is that the within transformation of Eq. 4 (errorcomponent model) be taken such that we have:

Yit $=\alpha_{1} X i t+V i+Y i t$ we have:

By averaging the equation over time for each firm,

$\overline{\mathrm{Y}} \mathrm{i}=\alpha_{1} \overline{\mathrm{X}} \mathrm{i} \times \mathrm{vi}+\overline{\mathrm{Y}} \mathrm{i}$

By taking 9 from 8 we have:

Yit $-\bar{y} i=\alpha_{1}(X i t-\bar{X} i)+Y i t-\bar{Y} i$

Equation 10 which is the time demean model can be estimated by pool OLS (Fixed Effect (FE) estimator)).

Sources of data and definition of variables: In the study, the variables earnings per share (eps), dividend per share (dps), debt and equity were used for the period between 1999 to 2005. The Factbook which is a publication of the Nigerian Stock Exchange was used. Data on these different variables were collected for different firms which were Conoil Plc, Mobil Oil Nigeria Plc, Oando Plc and Total Nigeria Plc. The Leverage ratio (Levratio) for each of the firms was determined using data for debt and equity.

\section{RESULTS AND DISCUSSION}

In an attempt to investigate the relationship that exist between earnings per share and leverage ratio on one hand and dividend per share and leverage ratio on the other hand in the petroleum industry examined in the study, effort was made to examine the descriptive statistic of the data series employed in the study. This is displayed in Table 1

Table 1 shows that eps has the largest standard deviation while levratio has the smallest standard deviation of 0.558 . The average value for eps, dps and levratio are $81.076,88.599$ and 0.556 respectively.

All the series in the study are positively skewed. The value of the kurtosis confirmed that the levratio is normally distributed.

The correlation matrix for the series used in the study is displayed in Table 2.
Table 1: Descriptive statistics of data used

\begin{tabular}{lrrr}
\hline & \multicolumn{1}{c}{ Eps } & \multicolumn{1}{c}{ dps } & Levratio \\
\hline Mean & 81.076 & 88.599 & 0.556 \\
Standard deviation & 234.309 & 216.066 & 0.558 \\
Variance & 54901.050 & 46684.500 & 0.312 \\
Skewness & 2.676 & 2.057 & 1.010 \\
Kurtosis & 8.458 & 5.270 & 2.811 \\
Observations & 28.000 & 28.000 & 28.000 \\
\hline
\end{tabular}

Source: Data analysis

Table 2: Correlation Matrix

\begin{tabular}{llll}
\hline & Eps & Dps & Levratio \\
\hline Eps & 1.0000 & & \\
Dps & 0.8450 & 1.0000 & \\
Levratio & 0.2722 & 0.2905 & 1.0000 \\
\hline
\end{tabular}

Source: Data analysis

Table 3: Results of the panel data for the Eps equation

\begin{tabular}{lccc}
\hline Variable & $\begin{array}{l}\text { Pooled } \\
\text { regression }\end{array}$ & $\begin{array}{l}\text { Fixed effect } \\
\text { estimation }\end{array}$ & $\begin{array}{l}\text { Random effect } \\
\text { estimation }\end{array}$ \\
\hline Constant & - & 83.8920 & 17.5610 \\
Levratio & 208.655 & -5.0610 & 114.1400 \\
$\mathrm{R}^{2}$ within & - & 0.0002 & 0.0002 \\
$\mathrm{R}^{2}$ between & - & 0.9081 & 0.9081 \\
$\mathrm{R}^{2}$ & 0.090 & 0.0741 & 0.0741 \\
Wald test & - & - & $2.08(0.14)$ \\
F-statistic & $2.40(0.13)$ & $3.20(0.04)$ & - \\
Sigma_u & - & 157.970 & 0.0000 \\
Sigma_e & - & 205.170 & 205.1700 \\
rh0 & - & 0.372 & 0.0000 \\
\hline Diagnostic test & & \\
Lagrangian Multiplier (LM) test & & $0.85(0.356)$ \\
Likelihood-ratio (LR) test & & $1.16(0.141)$ \\
Hausman test & & & $2.37(\mathrm{PV}=0.63)$ \\
\hline Source: Data analysis & &
\end{tabular}

Source: Data analysis

From Table 2, it is found out that all the variables are positively correlated. For instance, the correlation between eps and levratio is 0.27 while between levratio and dps is 0.2905 . However, between eps and dps the correlation coefficient is 0.84 .

To be able to measure the relationship that exist between eps and levratio panel data of this study, the different methods which include pooled regression, fixed effect regression and random effect regression were employed. The results from these methods are shown in Table 3, while the result for the relationship between dps and levratio was displayed in Table 4 .

The result on the Table 3 shows the results of the EPS equation for pooled regression, fixed effect regression and random effect estimation. For the pooled regression, result shows that a change in levratio will lead to 208.653 changes in eps.

The $\mathrm{R}^{2}$ shows that $0.09(9 \%)$ of the systemic variation in eps was explained by the levratio. However since panel data is applied in the study, the system of pooled regression is subject to heterogeneity bias and so therefore the fixed effect and random effect regression were employed. 
J. Math. \& Stat., 6 (2): 168-173, 2010

Table 4: Results of the panel data for the dps equation

\begin{tabular}{lccc}
\hline Variable & $\begin{array}{l}\text { Fixed effect } \\
\text { estimation }\end{array}$ & $\begin{array}{l}\text { Random effect } \\
\text { estimation }\end{array}$ & $\begin{array}{l}\text { Maximum likelihood } \\
\text { estimation }\end{array}$ \\
\hline Constant & 101.8900 & 26.9233 & 85.272 \\
Levratio & -23.9000 & 110.8430 & 5.978 \\
$\mathrm{R}^{2}$ within & 0.0057 & 0.0570 & \\
$\mathrm{R}^{2}$ between & 0.9107 & 0.9107 & \\
$\mathrm{R}^{2}$ & 0.0844 & 0.0800 & \\
Wald test & - & $2.34(0.12)$ & \\
F-statistics & $0.13(0.72)$ & - & \\
Sigma_u & 179.72 & 7.5400 & 134.330 \\
Sigma_e & 165.79 & 165.7900 & 163.030 \\
rh0 & 0.54 & 0.0020 & 0.404 \\
\hline Hagnostic test & & \\
Lagrangian Multiplier (LM) test & $4.94(0.02)$ \\
Likelihood- Ratio (LR) test & $5.29(0.011)$ \\
Hausman test. & & $1.83(0.10)$ \\
\hline
\end{tabular}

Source: Data analysis

For the fixed effect, result shows that an increase in the levratio will lead to reduction in the eps. That is there is an inverse relationship between eps and levratio. Any increase in levratio will reduce the eps to the tune of 5.061. On the other hand, the randomeffect indicates a positive relationship between the eps and the levratio. That is, a change in levratio leads to 114.14 changes in eps. To know which of the fixed effect or random-effect to be selected, the hausman test was carried out. Result shows the Value of the hausman test to be 2.37 and the P. Value is 0.63 . From this, the $\mathrm{P}$ Value is not significant and so therefore the random effect is selected.

The LM and LR test shows that there is problem of autocorrelation.

From the Table 4, the fixed-effect shows that there is an inverse relationship between levratio and DPS and for the random effect, there is a positive relationship between DPS and levratio. The random effect was also selected based on the hausman test carried out in the test. The $\mathrm{R}^{2}$ within shows that out of the whole systemic variation in the DPS, levratio was able to explain just $5.7 \%$ of the variation. The LM and its LR results show that there is no autocorrelation.

\section{CONCLUSION}

The study empirically analyzed the relationship existing between leverage and corporate performance in Nigerian Petroleum Industry using panel data analysis. From the empirical investigation conducted, the following are the findings and possible areas of intervention:

- That there is a positive relationship between earnings per share (eps) and leverage ratio. This implies that an increase in leverage ratio leads to increase in earnings per share
Also, there is a positive relationship between dividend per share (dps) and leverage. The implication of this is that if the leverage ratio of the Nigerian Petroleum Industry is increased, the dividend per share will also increase

- Based on these findings, it can be concluded that leverage ratio has significant positive effect on both the earnings per share and dividend per share. As a result of this, for the Petroleum Industry to continue to strive in Nigeria, their management should do much to improve on the leverage ratio

\section{REFERENCES}

Andy, C.W.C., C.Y.K. Chuck and E.L. Alison, 2002. The determination of capital structure: Is national culture a missing piece to the puzzle. J. Int. Bus. Stud., 33: 19-32. http://www.jstor.org/pss/3069576

Booth, L., A. Varouj, A. Demirguc-Kunt and V. Maksimovic, 2001. Capital structures in developing countries. J. Finance, 56: 87-130. http://www.jstor.org/pss/222464

Brealey, R.A. and S.C. Myers, 1996. Principles of Corporate Finance. 5th Edn., McGraw-Hill, USA., pp: 447-473.

Champion, D., 1999. Finance: The Joy of Leverage. Harvard Bus. Rev., 77: 19-22.

Demirguc-Kunt, A. and V. Maksimovic, 1999. Institutions, financial markets and firms debt maturity. J. Fin. Econ., 54:295-336. http://ideas.repec.org/a/eee/jfinec/v54y1999i3p295 $-336 . \mathrm{html}$

Edo, S.E., 1997. Private sector dependence on capital market funds in Nigeria: An empirical evidence. J. Econ. Manage., 4: 41-60.

Emmanuga, C., 1998. The Capital Market and Nigeria's Economic Performance. The capital market and Nigeria's economic development. Proceedings of the One-Day Seminar held at the Nigerian Institute of International Affairs, Jan. 21, Organized by the Nigerian Economic Society, Lagos, pp: 19-38.

Israel, R., 1992. Capital and Ownership Structure and the Market for Corporate Control. Rev. Fin. Stud., 5: 181-198. http://www.jstor.org/pss/2962029

Modigliani, F. and M.H. Miller, 1958. The cost of capital, corporation finance and the theory of investment. Am. Econ. Rev., 48: 261-297. http://www.jstor.org/pss/1809766

Noe, T., 1988. Capital structure and signaling game equilibria. Rev. Fin. Stud., 1: 331-356. http://rfs.oxfordjournals.org/cgi/content/short/1/4/3 31

Olowe, R.A., 1998. Financial Management; Concepts, Analysis and Capital Investments. 1st Edn., Brierly Jones Nigeria Ltd, Lagos, pp: 361-391. 
Oloyede, J.A. and S.O. Akinmulegun, 1999. Effect of capital structure on corporate performance of selected quoted companies in Nigeria: A preliminary investigation. Niger. J. Bank. Fin. Iss., 2: $119-128$.

Pandey, I.M., 1999. Financial Management. 8th Edn., Vikas Publishing House PVT Ltd. New Delhi, India, pp: 529-559.

Rajan, R.C. and L. Zingales, 1995. What do we know about capital structure, some evidence from international data. J. Finance, 50: 1421-1460. http://ideas.repec.org/a/bla/jfinan/v50y1995i5p142 1-60.html

Ross, S.A., 1977. The determination of financial structure: The incentive signaling approach. Bell. J. Econ., 8:23-40. http://ideas.repec.org/a/rje/bellje/v8y1977ispringp2 3-40.html
Van Horne, J.C., 2002. Financial Management and Policy. 12th Edn., Prentice-Hall of India Private Ltd. New Delhi, ISBN-10: 0130326577, pp: 253-287.

Vermale, T., 1981. Common stock repurchases and market signaling: An empirical study. J. Fin. Econ., 9: 139-189. http://ideas.repec.org/a/eee/jfinec/v9y1981i2p139183.html

Wald, J.K., 1999. How firm characteristics affect capital structure: An international comparison. J. Fin. $\quad$ Res., 22: 161-187. http://ideas.repec.org/a/bla/jfnres/v22y1999i2p16187.html 